\title{
Lumen
}

Selected Proceedings from the Canadian Society for Eighteenth-Century Studies

\section{Modes of Communication in Anna Barbauld's "On a Lady's Writing"}

\section{Lisa Vargo}

Volume 28, 2009

URI : https://id.erudit.org/iderudit/1012042ar

DOI : https://doi.org/10.7202/1012042ar

Aller au sommaire du numéro

Éditeur(s)

Canadian Society for Eighteenth-Century Studies / Société canadienne d'étude du dix-huitième siècle

ISSN

1209-3696 (imprimé)

1927-8284 (numérique)

Découvrir la revue

Citer cet article

Vargo, L. (2009). Modes of Communication in Anna Barbauld's "On a Lady's Writing". Lumen, 28, 127-137. https://doi.org/10.7202/1012042ar

Copyright (C Canadian Society for Eighteenth-Century Studies / Sociéte canadienne d'étude du dix-huitième siècle, 2009
Ce document est protégé par la loi sur le droit d'auteur. L'utilisation des services d'Érudit (y compris la reproduction) est assujettie à sa politique d'utilisation que vous pouvez consulter en ligne.

https://apropos.erudit.org/fr/usagers/politique-dutilisation/ 


\section{8: Modes of Communication in Anna Barbauld's "On a Lady's Writing"}

Media and communication are matters central to Anna Barbauld's witty and enigmatic "On a Lady's Writing," which first appeared in Poems (1773):

Her even lines her steady temper show;

Neat as her dress, and polish'd as her brow;

Strong as her judgment, easy as her air;

Correct though free, and regular though fair:

And the same graces o'er her pen preside

That form her manners and her footsteps guide. ${ }^{1}$

Less clear is the perspective that Barbauld takes in her brief poem. Critics are divided as to whether the phrase "a Lady's Writing" alludes to the lady's skill at poetry, to her penmanship, or to a combination of both. On the one hand, we have Angela Leighton's observation, that "The idea that metrical correctness is equivalent to moral propriety continued into the nineteenth century, at least as far as women's poetry was concerned. Anna Barbauld had laid down the rules, in the previous century, in 'On a Lady's Writing.'"'² On the other, Richard Sha gently takes the work to task because it "refuses to consider women's writing as anything but 'correct' strokes of the pen." ${ }^{\prime 3}$ If looking at the poem as

1 Anna Barbauld, The Poems of Anna Letitia Barbauld. Ed. William McCarthy and Elizabeth Kraft (Athens: University of Georgia Press, 1994), p. 70. Hereafter abbreviated Poems.

2 Angela Leighton, Victorian Women Poets: Writing Against the Heart (Brighton: Harvester, 1992), p. 38.

3 Richard Sha, The Visual and Verbal Sketch in British Romanticism (Philadelphia: University of Pennsylvania Press, 1998), p. 111. 
being concerned with the physical act of writing might seem to invite a willfully narrow interpretation, doing so also allows for a reading of the poem as an inclusive vision of women's place in society, one that is defined by reason and rights and which extends the boundaries of some of the more restrictive norms of conduct expected of middle-class women in the late eighteenth century.

As is well documented, during the eighteenth century writing became an important technology for reasons that mostly exclude women. The appearance of copybooks is related to the rise of English commerce, for which a round, flowing hand for business correspondence was developed. In one of the most celebrated manuals, The Universal Penman (1743), George Bickham states that his book is intended for the "Gentleman and Scholar, as well as the Man of Business." If his audience of users is select, he assumes that both his Gentleman and Lady subscribers will more generally recognize the importance of his enterprise: "That you may All long continue to promote and encourage This, and every other Useful Art, in which the Interest and Glory of your Country is any way concerned, and become Shining Examples of Virtue and good Manners. ${ }^{\prime 5}$ For Bickham, the art of writing involves a national project that demonstrates the "unrivalled" attainments of writing and engraving in Britain. He repeats these sentiments in The Surrey and Southwark Writing-Master, which includes brief essays on writing, the pen, and proper postures for holding the pen, as well as descriptions of different hands. ${ }^{6}$ While the subtitle ("The Whole contrived for the Use of both Sexes") may suggest otherwise - the content of the essays is directed to "Men in all Employments." ${ }^{\prime 7}$ If women nominally are included in his project - which is a class-based one - Bickham seems more concerned with how the female sex might recognize the value of the hand rather than on the particulars of their own practice of it.

4 George Bickham, Engrav'd by George Bickham. London, 1743. Eighteenth Century Collections Online. Gale Group.

http://galenet.galegroup.com.cyber.usask.ca/servlet/ECCO, p. 2.

5 Ibid., p. 4.

6 The Surrey and Southwark writing-master. A new county copy-book. Containing, an accurate, though compendious description of the above county,... To which is added, an essay towards a further improvement of a hand for business; ... Written, and engraved on copper plates, by George Bickham. [London], [1750?].

Eighteenth Century Collections Online Gale Group.

http://galenet.galegroup.com.cyber.usask.ca/servlet/ECCO.

7 Ibid., p. 2 
In spite of the comprehensive scope implied by the title of Bickham's work, women at the time were not seen as truly belonging to this "universal" realm. The eighteenth century not only clearly demarcated hands; the differences between reading printed text and decoding handwriting were more pronounced than they are now, and print literacy did not necessarily mean one was able to read handwriting. ${ }^{8}$ If round hand was assumed to communicate the virtue and good manners of the gentleman, scholar, and man of commerce, the kind of handwriting women were expected to use was the italic or Italian hand, which was considered both easy to learn and feminine in appearance. Accordingly Italian hand was intended to communicate values associated with the feminine. In his copy book A Delightful Recreation (1717), William Brooks uses the Italian hand to advertise his skill at teaching the "Ladies of Great Britain" a hand "which as your own I recommend to your choice and practice, being full of Beauty, Ornament and Delight, and Invented for the Sole use and Embellishment of your fair Sex." ${ }^{\prime 9}$ Brooks makes clear the values inscribed in a woman's hand. "Sole use" may appear to suggest privilege and exclusivity, but the term in fact signifies how women are separated from forms of communication that embody power. At the same time "Beauty, Ornament and Delight" as well as "Embellishment" suggest how women are seen both as a consumable commodity and as consumers of the commercial, roles quite different from those that Bickham assigns to men.

Thus different hands communicated to Barbauld's contemporaries distinctions of class, gender, and occupation. In particular, bodily discipline and feminine propriety are conveyed by a lady's hand; handwriting is also an expression of sensibility. As Clare Brant observes, "references to blots and smudges evoked emotions too powerful for the writer's body to control. Imaged through a falling tear or a trembling 'hand,' these excitements wrought effects visible in script, invisible in print; the supposed loss becomes itself a metaphor of inexpressibility." ${ }^{10}$

8 See David Cressy, "Literacy in Context: Meaning and Measurement in Early Modern England," in Consumption and the World of Goods, eds. John Brewer and Roy Porter (London: Routledge, 1993), pp. 311-12.

9 A delightful recreation for the industrious. A copy book of plain and practical writing ... Invented $\mathcal{E}$ performed by, William Brooks. ... Georgius Bickham Londini sculp. London, [1750?]. Eighteenth Century Collections Online. Gale Group. http://galenet.galegroup.com.cyber.usask.ca/servlet/ECCO.

10 Clare Brant, Eighteenth-Century Letters and British Culture (Basingstoke: Palgrave, 2006), p. 8. 
Female character delineated through handwriting makes its appearance as an element in the epistolary genre at this time. In their notes to "On a Lady's Writing," Barbauld's modern editors make reference to volume five of Samuel Richardson's Clarissa (1748), where Lovelace observes to his friend John Belford that Clarissa's "delicate and even mind is seen in the very cut of her letters."11 In fact Barbauld's poem keeps company with a number of contemporary works that concern women's letter writing. Richardson's works, Henry Fielding's parody An Apology for the Life of Mrs. Shamela Andrews (1741) and Frances Burney's sentimental novel Evelina (1778) demonstrate the versatility of the epistolary novel in its exploration of female behaviour, while Tobias Smollett's Humphrey Clinker (1771) notably examines degrees of female literacy and varieties of class distinction in the characters of Lydia Melford, Tabitha Bramble, and Winifred Jenkins. Handwriting continues into the nineteenth century to serve as a marker of gender in fiction. Jane Austen's writings are full of references to the act of letter writing. In Volume 1, chapter ten of Pride and Prejudice (1813) Miss Bingley comments on Mr. Darcy's handwriting and the "evenness of his lines." Volume 2, chapter 16 of Emma (1816) includes a discussion of the varieties of handwriting during which Mr. Knightley criticizes Frank Churchill's handwriting for being too much like a woman's. ${ }^{12}$ While Barbauld would been acquainted with Pope's 1717 epistolary poem "Eloisa to Abelard," Lord Byron's description of the handwriting of Donna Julia near the end of Canto One of Don Juan (1819) also draws upon Pope in its equation of handwriting and bodily emotion: "This note was written upon gilt-edged paper / With a neat little crow-quill, slight and new: / Her small white hand could hardly reach the taper, / It trembled as magnetic needles do. ${ }^{\prime 13}$ But a woman's handwriting is more than merely a marker of virtue or social class. Barbauld is aware that the display of emotion or propriety allows for some range within the discipline of the hand, and it is in this interplay between sentiment and reason that Barbauld locates space for a perspective which does not strictly follow social convention.

11 Poems, p. 264.

12 Thanks to Mary Chan, University of Alberta for this reference.

13 Lawrence Lipking notes that it caused Byron's friend Percy Shelley to call it "a masterpiece of portraiture" and ask, "Where did you learn all these secrets?" See "Lord Byron's Secret: The School of Abandonment." Abandoned Women and Poetic Tradition (Chicago: University of Chicago Press, 1988), p. 34. 
Barbauld's poem can be said to form a kind of alternative copy book, recognizing as it does that even if women's writing is exclusive of commercial concerns, it is nevertheless of importance. Here one might invoke her opinions on the education of women and her notorious rejection of involvement with an academy for women, aspects of her life and character which have been subject to considerable puzzlement and controversy. ${ }^{14}$ Like her perspective on women's education, which is not a rejection of female potential but a matter of pragmatics and situated in a complex web of personal and social concerns, in seemingly arguing for less, Barbauld might be seen to be suggesting a realistic and practical way to achieve more. In "On a Lady's Writing" she invokes an inclusive principle of the rights of the person. A key text in this discussion is the series of undated letters posthumously published in 1826 by her niece Lucy Aikin as an epistolary essay entitled "On Female Studies." In the subjects they might learn, Barbauld notes that women are "excused from all professional knowledge" relevant to careers in professions and in business. ${ }^{15}$ However, she prefaces this admission with a more general statement: "Every woman should consider herself as sustaining the general character of a rational being," and in this she believes "the motives for acquiring general knowledge and cultivating the taste are nearly the same to both sexes." ${ }^{16}$ One might apply her discussion of gender and education to male and female handwriting. If one hand conveys professions and business and another suggests exclusion from this realm, Barbauld nevertheless believes that both hands share some more fundamental qualities. This is implied by how the poem rewrites the social script represented by Brooks in his copy book. Barbauld's poem echoes some of the attitudes represented in Brooks's notice that

In "Why Anna Letitia Barbauld Refused to Head a Women's College: New Facts, New Story." Nineteenth-Century Contexts 23 (2001), 349-79, William McCarthy presents a careful reading of a private letter Barbauld wrote, which was excerpted in her niece Lucy Aikin's biography. The letter was not addressed to Elizabeth Montagu, as has commonly been assumed, but to Rochemont Barbauld. While McCarthy suggests that her declining the proposal has to do with issues like Rochemont going behind her back and using her literary reputation, as well as an anxiety that the school would take time away from her writing, Aikin used the letter to create a version of her aunt which would be in keeping with nineteenth-century notions of propriety for women.

15 Anna Barbauld, "On Female Studies," Anna Letitia Barbauld: Selected Poetry and Prose, eds. William McCarthy and Elizabeth Kraft (Peterborough: Broadview, 2002), p. 475. 
handwriting might reveal feminine character; but rather than limiting her recommendations to the more superficial qualities of "Beauty, Ornament and Delight" which are "Invented for the Sole use and Embellishment of your fair Sex," Barbauld looks to the matters of knowledge and taste that she believes belong to both sexes.

Certainly a part of this enablement is reflected in the rhyme and metre of the poem. Metrical correctness suggests not only the poet's propriety, but also that of women in general. The rhyming couplets reflect steadiness and regularity but do so in an unobtrusive form. The mostly end-stopped lines and appearance of caesuras demonstrate balance. The ease is communicated by word choice: only one word of the fortyseven in the poem ("regular") has three syllables, while the majority of the words (thirty-four) are of a single syllable. The repetition of "her" in every line but one and in most balanced on either side of a caesura again reinforces steadiness and regularity. The poem is for the most part metrically regular iambic pentameter with some inversions at the beginnings of lines for emphasis. The interplay between regularity and freedom rhythmically echoes the line "Correct though free," as the poem is not absolutely bound by the iambic meter, but makes room for variation. The rhyme scheme likewise allows for some departure from regularity in that the "preside / guide" rhyme at the end of the poem is at variance with the other one-syllable word rhymes. As is the case with meter and rhyme in the poem, the female hand is not one bound to convention; judgment makes possible autonomy and free play within the demands of correctness and regularity, thereby "sustaining the general character of a rational being."

The unspecified identity of the lady being described represents a departure from other poems in Barbauld's first published volume. Many of the works Barbauld included in Poems (1773) are addressed to members of her family or to friends associated with the Warrington Academy; the indefinite article in "a Lady" and the focus on handwriting suggest that Barbauld is not concerned with a particular person's identity, though "Lady" does suggest social demarcations. The translation of a poem about handwriting into a printed form takes the poem away from association with a specific individual towards more general consideration of the practice of writing as one of the many accomplishments a lady need acquire, as Barbauld similarly suggests in the sketch likely addressed to her sister-in-law: "Her ready fingers plied with equal skill / The pencil's task, the needle, or the quill."17 
One interpretation of this anonymity is that it signifies "privacy, modesty, and restraint," qualities which form an implicit critique of social and political institutions. ${ }^{18}$ In her essay on Barbauld and the "Illegible Signature," Susan Rosenbaum argues that "Barbauld develops a lyric aesthetic based on the miniature" to "define a circulation distinct from the dominant, commercially controlled circuits of exchange."19 This "miniaturist aesthetic" is "opposed to capitalist expansion in its imperialist variety, and to its poetic counterpart, the expansive romantic self." ${ }^{\prime 20}$ For Rosenbaum the "illegible signature" divests the poem "of particularity such that it comes to stand for all ladies, and perhaps for the common practice of signing a poem as 'a lady.'" ${ }^{21}$ In resisting the specificity of addressing her poem to a particular lady, Barbauld rejects forms of celebrity and of commercial circulation. She establishes, Rosenbaum argues, "an economy of exchange based not on the commodity-for-sale, but on the gift," a quality which suggests a form of labour that is private in its circulation and resists the public and the commercial. $^{22}$

While the distinction between court hand and italic hand suggests alternative modes of communication, that distinction need not lead to opposition or critique. I want to revisit Barbauld's statement in "On Female Studies" that, even if women were "excused from all professional knowledge," nevertheless "Every woman should consider herself as sustaining the general character of a rational being" and "the motives for acquiring general knowledge and cultivating the taste are nearly the same to both sexes. ${ }^{\prime 23}$ It is important to remember that Barbauld's letters on female education reflect values of candour and free inquiry that characterize her Dissenting background. Barbauld balances the recognition of social constraints upon women with the belief that such restraints need not be accompanied by limitations on moral and intellectual abilities. Her poem suggests how the discipline of the italic hand enables women to communicate their abilities in a manner that includes confidence and equanimity. Although she did not shrink

18 Susan Rosenbaum, "'A Thing Unknown Without a Name': Anna Laetitia Barbauld and the Illegible Signature," Studies in Romanticism 40 (2001), 371.

19 Ibid., p. 372.

20 Ibid.

21 Ibid., p. 387.

22 Ibid., p. 389.

23 Barbauld, Poetry and Prose, p. 475. 
from protesting the "Sins of Government," Barbauld also "dwells in possibility" with respect to women's place in society. In the Dedication to Letters on the Improvement of the Mind (1773), a collection of correspondence written to her niece, Hester Chapone addresses Elizabeth Montagu: "some strokes of your elegant pen have corrected these Letters" and she numbers an ability to "write a free and legible hand" among the "indispensable requisites" a lady might obtain. ${ }^{24}$ Like Chapone, Barbauld utilizes a vocabulary of conduct to problematise expectations about a lady's writing; and in a spirit of sociability similar to that which Chapone models, Barbauld engages in some gentle pushing against the boundaries of what proper female conduct was considered to entail. William Keach suggests of Barbauld, "Dissent has taught her to claim a critical freedom for herself that has to coexist both with intellectual and political solidarity and with the continuing relegation of women to the realm of nurturing domesticity." ${ }^{25}$ But how does one claim such freedom within such regulation?

One possibility is to look more closely at the physical nature of writing and consider what it might reveal about her immersion in contemporary notions of self and identity. Kathryn Ready has traced Barbauld's engagement with John Locke's claim in the second edition of An Essay Concerning Human Understanding (1694) "that self is not determined by Identity ... of Substance ... but only by Identity of consciousness." ${ }^{26}$ Ready examines how the group of poems entitled Characters and included in Poems (1773) represents "an attempt to develop some of the feminist implications of Locke's statements about the nature and identity of the self." If "Barbauld resists the most radi-

24 Chapone, Mrs. (Hester), Letters on the Improvement of the Mind, Addressed to a Young Lady. A new edition (London, 1786), p. iv, p. 172. By way of comparison, see Clare Brant's mention of Wettenhall Wilkes' A Letter of Genteel and Moral Advice to a Young Lady (London, 1746), where advice about handwriting is "shortly followed by an injunction never to appear in company without stays" (349n). Wilkes believes that "To write a fine Hand, is a great Ornament to a young Lady, and is either envy'd, or prais'd, by every one. This is therefore a necessary improvement. As an Italian hand, is not fit for Business, and as it bears a mean Aspect, if not wrote genteely well, a fair Round-hand appears to me to be the most useful" (Wetenhall Wilkes, $A$ Letter of Genteel and Moral Advice to a Young Lady: Being a System of Rules an Informations ... $4^{\text {th }}$ ed. [London, 1746], p. 186).

25 William Keach, "Barbauld, Romanticism, and the Survival of Dissent," Romanticism and Gender, ed. Anne Janowitz. (Cambridge: D.S. Brewer, 1998), p.50.

26 Kathryn Ready, "Identity, Character, and Gender: Anna Barbauld and Pope's Characters of Men and Women." Women's Writing 11(2004), 378. 
cal feminist implications of the theory of self-in-consciousness," Ready argues, the poems "aim at stabilising the relationship between gender and identity in a way that affirms the sexual division of labour, even as they stress the value of women's work." ${ }^{\prime 2}$ In the section "Of Identity and Diversity" in Locke's Essay, Barbauld would have encountered the idea of the mind as a tabula rasa and of a sense of self developing from experience. Accordingly, Ready argues, male and female identity are the result of experience, "in which context education evidently plays a crucial role." 28 As "On a Lady's Writing" has been connected with Characters, it is possible to apply Ready's argument to that poem and consider how Barbauld's thoughts about notions of identity extend to handwriting. While italic and round hands are products of different experience, the differences do not preclude women's potential and are not matters of substance with respect to identity.

With this awareness of Barbauld's grounding in philosophical arguments about identity and how experience might transform potential, one sees how freedom is expressed in the poem through one of the most characteristic registers in her poetry: wit. Well-known works like "The Mouse's Petition," "Washing-Day" and "Inscription for an Ice-House" pursue matters of rights and the provenance of knowledge through the mock heroic and quiet irony. If there is a kind of Classical simplicity about its form and expression, "On a Lady's Writing" displays irony in that Barbauld reminds the reader of the discrepancy between what women are capable of and what society expects of them, more specifically what it expects women to do with their writing. On the one hand the reference to the dress and the polished brow and the easy air speak to the kinds of feminine accomplishment traced in conduct book literature. But allusions to concepts like judgment and freedom and to how one comports oneself within the social sphere suggest a view of women's physical and mental capabilities that has to do with issues of rights and responsibilities, issues that extend beyond the more superficial forms of conduct. In her poem Barbauld embraces a politics against exclusion that is in keeping with her views on slavery, the Test Acts, and other violations of rights. So the problem Barbauld addresses in her poem is not anything as focused as women's place in literature or women's claim to a court hand. Her purpose, as I have argued, is a more fundamental one: to demonstrate how in the very act of handwriting, women communicate their abilities to demonstrate reason and taste, be 
it through the public documents of the poem or novel or through the private writings of the letter or diary. This is the object of the preposition "on" in "On a Lady's Writing."

The possibility of critical freedom within regulation is demonstrated by how the poem itself was communicated beyond the pages of Barbauld's Poems. Its circulation confirms its public and private aspects, and that it was read by its contemporaries as being not so much about women's handwriting per se as about what it represents with regard to female capabilities. Mary Wollstonecraft included the poem in The Female Reader (1789), a cultural project intended "to imprint some useful lessons on the mind, and cultivate the taste at the same time. ${ }^{\prime 29}$ Moira Ferguson calls Wollstonecraft's Preface, in which Barbauld's "Thoughts on the Devotional Taste" (1775) is quoted at length, "one of the most advanced articulations of a woman's right to think and to be educated until that time. Beyond that, her program and methodology, as a variation on the respect paid to oral argumentation in the century, indirectly challenge women's exclusion from that development. ${ }^{\prime \prime 30}$ Wollstonecraft's inclusion of "On a Lady's Writing" unites the possibilities of overcoming the different valuations of male and female hands with Wollstonecraft's own project of uniting oral argumentation with the right to think.

At the same time the poem embodies a more private cultural practice that reclaims the printed page to writing. It is significant that a copy of the poem appears in an early nineteenth-century miscellany produced in manuscript by a lady, where it is titled "On Miss C-'s Writing." (The manuscript is in the University of Chicago Library.) Barbauld's modern editors, William McCarthy and Elizabeth Kraft, suggest they have no knowledge of the provenance of the manuscript or of the identity of Miss C. ${ }^{31}$ The copy and its anonymity represent Barbauld's point. The poem's renaming and appearance in a lady's actual handwriting embody the very negotiation between public and private with which Barbauld is concerned. Presumably the creator of the miscellany copied the poem because it reminded her of her friend Miss C. In so doing the

29 Mary Wollstonecraft, The Female Reader; or Miscellaneous Pieces in Prose and Verse; Selected from the Best Writers, and Disposed Under Proper Heads ... (London, 1789), p. iv.

30 For the quotation from "an essay which does honour to a female pen," see Wollstonecraft, "Preface," The Female Reader, pp. ix-xii. Moira Ferguson, "The Discovery of Mary Wollstonecraft's 'The Female Reader,'" Signs 3 (1978), 948.

31 Poems, p. 264. 
lady had the opportunity to consider what the poem signifies about the power of writing by applying it to a particular personal context.

We may not place the same kinds of value on particular hands or view them in the same manner as Barbauld's age did, but the poem retains a deep significance in forging a link between literacy and rights. From her perspective as a Dissenting thinker, Barbauld asks ladies to use their literacy to change society's inscription of middle-class women. In that respect the poem might remind us, as inheritors of the Enlightenment, how literacy has the potential to contain or to free members of a society, depending upon whether we choose modes of communication which include or exclude individuals. ${ }^{32}$

LISA VARGO

University of Saskatchewan

32 To view an electronic edition of Barbauld's Poems and for additional information on handwriting, see Anna Lætitia Aikin [later Barbauld], Poems (1773), eds., Lisa Vargo and Allison Muri. Romantic Circles Electronic Editions,

http://www.rc.umd.edu/editions/ contemps/barbauld/poems1773/. 